\title{
Late quaternary sea level changes of Gabes coastal plain and shelf: Identification of the MIS 5c and MIS 5a onshore highstands, southern Mediterranean
}

\author{
Maher Gzam*, Noureddine El Mejdoub and Younes Jedoui \\ U.R. Applied Hydrosciences, Higher Institute of Water Sciences and Technics, University of Gabes, \\ Zrig 6072 Gabes, Tunisia. \\ ${ }^{*}$ Corresponding author.e-mail: gzammaher79@gmail.com
}

\begin{abstract}
The continental shelf of the Gulf of Gabes is outlined, during the MIS 5c and MIS 5a onshore highstands, by the genesis of forced regressive beach ridges situated respectively at $-19 \mathrm{~m}$ b.s.l/100 ka and $-8 \mathrm{~m}$ b.s.l/80 ka. This area, considered as a stable domain since at least the last $130 \mathrm{ka}$ (Bouaziz et al. 2003), is a particular zone for the reconstruction of the late quaternary sea-level changes in the region. Shuttle Radar Topography Mission (SRTM) data and field observations are highlighted to deduce interaction between hydrodynamic factors and antecedent topography. Variations in geomorphology were attributed to geological inheritance. Petrography and sedimentary facies of the submerged coastal ridges reveal that the palaeocoastal morphology was more agitated than today and the fluvial discharges are consistent. Actual morphologic trend deduced from different environment coasts (sandy coasts, sea cliffs and tidal flat) is marked by accumulation of marine sands and progradation.
\end{abstract}

\section{Introduction}

The Gulf of Gabes (southeastern Tunisia, figure 1) has received considerable attention by scientists interested especially in eustatic sea-level signals (Paskoff and Sanlaville 1983; Morzadec-Kerfourn 2002; Jedoui et al. 2002, 2003; Morhange and Pirazzoli 2005; Anzidei et al. 2011), hydrodynamic processes (Abdennadher and Boukthir 2006; Sammari et al. 2006) and geodynamic evolution (Bouaziz et al. 2003; Patriat et al. 2003). The littoral of Jeffara basin (figure 1) provides an ideal site to study coastal changes at time scale, ranging from storm events to millennia, because large coastal forms exhibit short response time to external forces like winds, tide and RSL changes (Gzam et al. 2013, 2014; Mauz et al. 2015). The global MIS 5e sea-level curve includes two fluctuations: the rise before $130 \mathrm{ka}$, a period of stability (at 130$118 \mathrm{ka}$ ) some meters above modern sea level and the fall at $\sim 115 \mathrm{ka}$. There is some evidence for a second rise (at 124-122 ka) (Lambeck et al. 2002; Siddall et al. 2006; Rohling et al. 2007; Kopp et al. 2009), which is supported by RSL observations on the southeastern Tunisia (Jedoui et al. 2002). The Jeffara basin seems to provide onshore evidence for two highstands during MIS 5e (Jedoui et al. 2002, 2003), which is pretty unique. Here, the last interglacial was characterized by two eustatic maxima represented by two sediment units: a siliciclastic unit situated at $3 \mathrm{~m}$ above sea level (a.s.l), overlain by a carbonate-rich unit with Strombus bubonius at $5 \mathrm{~m}$ a.s.l (Jedoui et al. 2003). These units constitute a beach ridge parallel to the present day coast which overlay an erosional surface cutting the Mio-Pliocene deposits. The positions of the

Keywords. MIS 5c and MIS 5a; beach ridges; sea level changes; palaeocoastal morphology; Gulf of Gabes; Tunisia. 


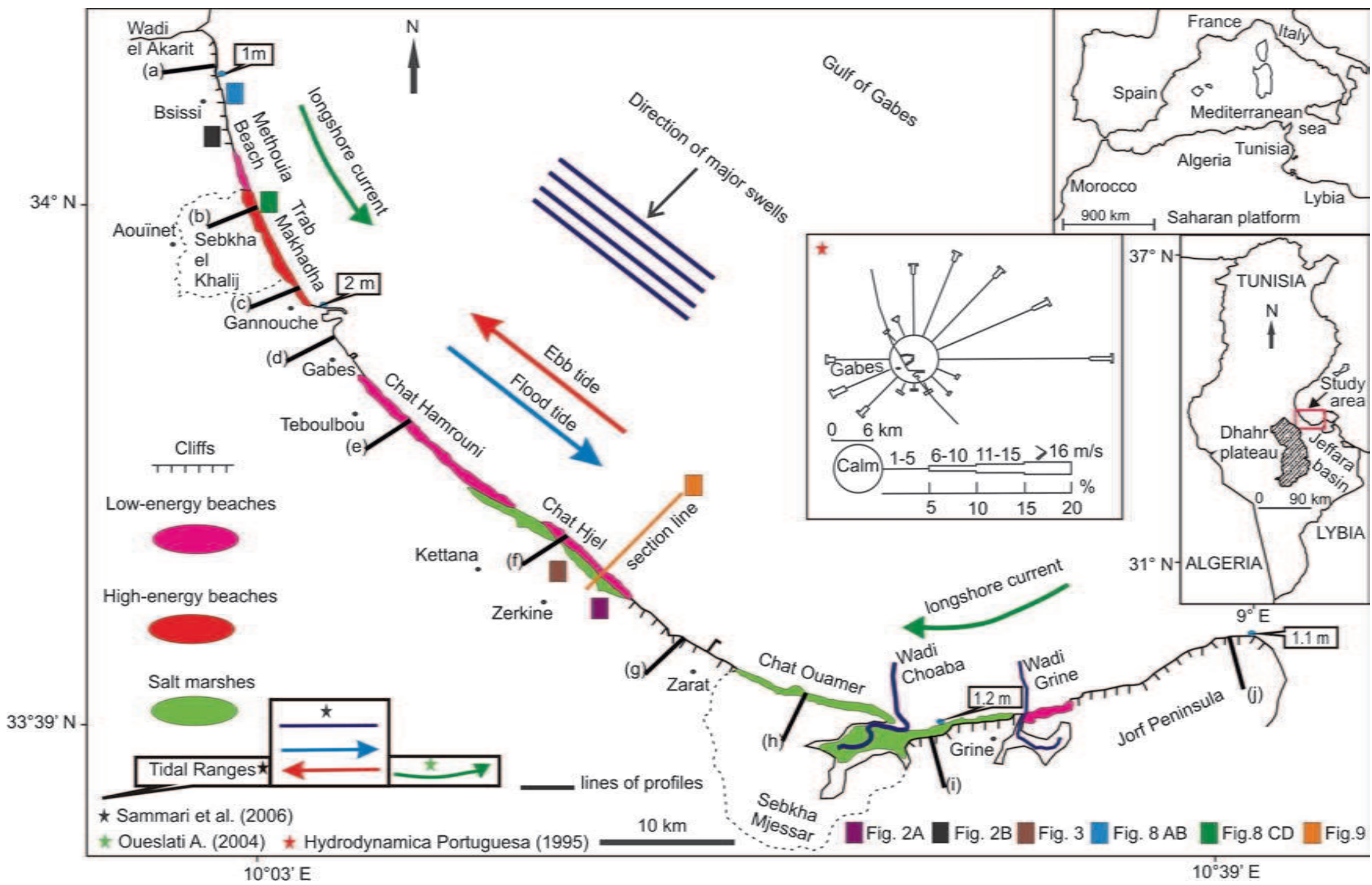

Figure 1. Location map of the study area including topographic lines, wind-diagram and the hydrodynamic conditions. 
regional shoreline during MIS 5c (100 ka) and MIS 5a (80 ka) sea-level highstands are assumed to be situated at -20 and $-10 \mathrm{~m}$ below sea level (b.s.l), respectively (Chappell and Shackleton 1986; Lea et al. 2002; Arz et al. 2007; Thompson et al. 2011). The configuration scheme of two submerged beach ridges (MIS 5c and MIS 5a) below modern sea level is aimed to be approved in the present study. This paper is a continuation of previous works in the southern Mediterranean (Jedoui et al. 2002,2003 ) that were supported by geomorphological, stratigraphic and sedimentological analysis. The southern edge of the Gulf of Gabes has been considered as stable domain since the last interglacial (Bouaziz et al. 2003). This hinge situation in the Mediterranean basin is promoted to give high precision reconstruction of the late quaternary sea level changes in the region. We paid particular attention to the disposition of two submerged beach ridges, situated around -19 and $-8 \mathrm{~m}$ b.s.l.

\section{Tectonic setting}

The Jeffara basin is a collapsed block of the Saharan platform and extends eastward into Libya and the Pelagian basin of the east Mediterranean. It is a result of normal faulting in NW-SE to NNWSSE direction in Jurassic time associated with the South Tunisian Fault (Bouaziz et al. 2003). The extensional processes were characterized by around $25 \mathrm{~m} / \mathrm{Ma}$ (Patriat et al. 2003) subsidence rate which increased in the Barremian to more than 50 $\mathrm{m} / \mathrm{Ma}$. Later, the basin was characterized by discontinuous and spatially diverse subsidence rates, where particularly the central part was affected by high rates of subsidence during the middle Eocene (Ellouz 1984). Finally, the Plio-Quaternary subsidence corresponds to the recent opening of the Pelagian Sea. The NW-SE faults are normal (Ben Baccar 1982), of which most significant is the Mednine Fault with offsets of up to several hundred meters. The faults of SW-NE directions strike the coastal plain at right angles and are accompanied by vertical movements (Ben Baccar 1982).

\section{Hydrodynamic conditions}

Tidal regime has an impact on the evolution of coastal morphology. In the Mediterranean, the highest tides are observed in the Gulf of Gabes (Abdennadher and Boukthir 2006), where tides are principally semi-diurnal in nature, while tidal range is not the same everywhere in the Gulf of Gabes. The tidal amplitude is highest $(2 \mathrm{~m})$ in the centre of the Gulf (Ghannouche, figure 1) and smaller in the south: $1.2 \mathrm{~m}$ at Grine and $1.1 \mathrm{~m}$ at Jorf (figure 1). Near shore, the tidal currents remained parallel to the coastline (Sammari et al. 2006) and their effect manifests, on the shoreface, by narrow channels where current velocities can reach $80 \mathrm{~cm} \mathrm{~s}^{-1}$ (Jedoui 1979). Tidal action manifests also by the migration of hydrodynamics zones (shoaling, breaking and swash) across the foreshore and the shoreface. The fluctuation of the water levels is punctuated by the ebb and flood periods which occur alternatively every 6 hrs. During a spring cycle-tide, ebb and flood period, the mobilisation and the transport of the sediments, along sandy coast, are important because the wave action modulate the sediments along a very large transverse profile. Furthermore, the bathymetry of the Gulf of Gabes is smooth and the water depth decreases gradually $(0.2 \%)$ from the open sea $(20 \mathrm{~m})$ to the coast. Several studies (Amari 1984; Abdennadher and Boukthir 2006; Sammari et al. 2006) show that, in the Gulf of Gabes, large wave amplitudes mainly correlate with high wind speed from NE direction. Wind directions at Gabes are predominantly northeasterly. Sea levels appear to rise in response to wind pile-up (Sammari et al. 2006). For wave generation, only the northeast wind direction provides a long fetch $(1200 \mathrm{~km}$, Amari 1984). After refraction, the wave, remaining oblique to the coastline, generates two long-shore currents flowing in two opposite directions (figure 1).

\section{Methods}

The study area belongs to the northern edge of Jeffara basin from $34^{\circ} 07^{\prime}-33^{\circ} 42^{\prime} \mathrm{N}$ and from $10^{\circ} 01^{\prime}-10^{\circ} 43^{\prime} \mathrm{E}$ (figure 1 ). Reconstructions of the palaeoshoreline, at different time scales, require geological records, field observations, stratigraphic correlations, petrographic thin-section analysis, clast compositional analysis and remote sensing. The shape and the geomorphologic setting of the coastal ridges were investigated in a manner to discern the interactions between eustasy and sediment supply by looking at the palaeoshoreline adjustment. Stratigraphic correlations are well-matched along Pleistocene coastal ridges taking into account lithology and facies changes. Facies correlation was established between coastal ridges which are situated at the same depth. The altitude of the MIS 5 e coastal ridge is considered as a tectonic marker of the relative stability of the coast. Actual morphologic trend of the coast is elucidated by remote sensing, where morphologic pattern in which the inter-relationship between sediment accumulation features and coastal morphology is provided. Several marine missions were organised in the Gulf of Gabes, where a high precision echo-sounder was deployed to estimate the bottom depth. Two beach 
ridges are repaired offshore at -8 and $-19 \mathrm{~m}$ b.s.l, with a lateral extend ranging from $2 \mathrm{~km}$ to $50 \mathrm{~m}$. These ridges culminate around $3-5 \mathrm{~m}$ above the bottom sea. Reliable data such as seafloors of sampling sites were measured with respect to the high watermark observed during the spring tide (tidal amplitude $=2 \mathrm{~m}$ ). In fact, sampling mission coincided with neap tide period where weather conditions are not severe and the tidal amplitude does not exceed $1 \mathrm{~m}$. A coefficient of $1 \mathrm{~m}$ was added to the water depth at each sampling site in a manner to equilibrate the maximum water level taking into account the local tidal range. More than 10 rocky samples are collected from the ridges. Petrographic thin-sections were performed from the sandstone samples, where the faunal content and matrix were specified. Macroscopic description is reserved, especially for the coarser facies (conglomerate samples), where the fossiliferous content, granule size and clasts were determined. Palaeo-morphologic

Table 1. Coastal morphology related to the topographic setting of the hinterland.

\begin{tabular}{|c|c|c|c|}
\hline Sites & $\begin{array}{l}\text { Hinterland altitude at } \\
4 \mathrm{~km} \text { from the coastline }\end{array}$ & Hinterland characteristics & $\begin{array}{l}\text { Littoral } \\
\text { morphology }\end{array}$ \\
\hline Bsissi & $40 \mathrm{~m}$ (a.s.l) & Smooth shapes and gently rolling surface & Cliff \\
\hline Aouïnet & $15 \mathrm{~m}($ a.s.l) & Flat lowland & Sandy beach \\
\hline Ghannouche & $47 \mathrm{~m}($ a.s.l) & High plateau gently inclined towards the coast & $\begin{array}{l}\text { Low cliff advanced } \\
\text { by sandy beach }\end{array}$ \\
\hline Gabes & $15 \mathrm{~m}($ a.s.l) & Coastal oasis & Sandy beach \\
\hline Teboulbou & $45 \mathrm{~m}($ a.s.l) & High plateau gently inclined towards the coast & Sandy beach \\
\hline Zerkine & $45 \mathrm{~m}($ a.s.l) & $\begin{array}{l}\text { Highland plateau denotes slope ruptures located } \\
\text { at } 2.5 \mathrm{~km} \text { from the coast }\end{array}$ & Sandy beach \\
\hline Zarat & $47 \mathrm{~m}($ a.s.l) & Highland area remains elevated with a regular slope & Cliff \\
\hline Mjessar & $15 \mathrm{~m}($ a.s.l) & Flat lowland & Salt marshes \\
\hline Grine & $25 \mathrm{~m}$ (a.s.l) & Hinterland topography is irregular and remains elevated & Cliff \\
\hline Jorf & $22 \mathrm{~m}$ (a.s.1) & Rolling surface with a moderate topographic variation & Cliff \\
\hline
\end{tabular}

Table 2. Morphogenetic setting of the Pleistocene coast (substage MIS 5e) along the northern band of Jeffara plain.

\begin{tabular}{|c|c|c|c|}
\hline Sites & Facies description & Localisation and lateral extension & Altitude \\
\hline $\begin{array}{l}\text { Wadi Zigzaou to } \\
\text { Zarat }\end{array}$ & $\begin{array}{l}\text { Medium to coarse grained sand } \\
\text { with shell debris (cardium and } \\
\text { gastropods) and scattered flattened } \\
\text { pebbles. Presence of planar } \\
\text { stratifications which characterize } \\
\text { swash zone deposits. Matrix consists } \\
\text { to fine sandstone. }\end{array}$ & $\begin{array}{l}800 \mathrm{~m} \text { from actual coastline. } \\
\text { Lateral extension exceed } \\
1 \mathrm{~km} \text {. Discontinuity of the } \\
\text { coastal ridge is caused by } \\
\text { wadi systems erosion. }\end{array}$ & $3 \mathrm{~m}$ a.s.l \\
\hline $\begin{array}{l}\text { Wadi Zerkine to } \\
\text { Wadi el Ferd }\end{array}$ & $\begin{array}{l}\text { Very coarse deposit made of well } \\
\text { flattened pebbles and abundant } \\
\text { shell (cardium and gastropods). } \\
\text { Absence of sedimentary structures. } \\
\text { Clasts correspond mainly to Mesozoic } \\
\text { limestone fragments. }\end{array}$ & $\begin{array}{l}800 \mathrm{~m} \text { from actual coastline. } \\
\text { Discontinuous lateral extension } \\
\text { which do not exceed } 2 \mathrm{~km} \text {. } \\
\text { Most part of the ridge is covered } \\
\text { by continental aeolian deposits. }\end{array}$ & $3 \mathrm{~m}$ a.s.l \\
\hline $\begin{array}{l}\text { Wadi el Ferd to } \\
\text { Wadi Tmoula }\end{array}$ & $\begin{array}{l}\text { Well rounded pebbles including Strombus } \\
\text { bubonus. The ridge is much altered. }\end{array}$ & $\begin{array}{l}500 \mathrm{~m} \text { from actual coastline. } \\
\text { Discontinuous lateral extension } \\
\text { which exceeds } 5 \mathrm{~km}\end{array}$ & $3 \mathrm{~m}$ a.s.l \\
\hline $\begin{array}{l}\text { Wadi Tmoula to } \\
\text { Wadi Sourrag }\end{array}$ & $\begin{array}{l}\text { Well rounded pebbles, including Strombus } \\
\text { bubonus. Pebbles and shells are incorporated } \\
\text { in fine sandstone. Absence of sedimentary } \\
\text { structures. }\end{array}$ & $\begin{array}{l}900 \text { m from actual coastline. } \\
\text { Discontinuous lateral extension } \\
\text { which exceeds } 3 \mathrm{~km} \text {. Most part } \\
\text { of the ridge is covered by a well } \\
\text { developed gypsum layer. }\end{array}$ & $5 \mathrm{~m}$ a.s.l \\
\hline Aouïnet & Total desperation of Pleistocene coasts? & Not found? & Not found? \\
\hline Bsissi region & $\begin{array}{l}\text { Fine grained bioclastic quartz rich sand } \\
\text { devoid of Strombus bubonus. Presence } \\
\text { of planar stratifications with sparse } \\
\text { pebbles. }\end{array}$ & $\begin{array}{l}100 \text { m from actual coastline. } \\
\text { Lateral extension exceeds } 1 \mathrm{~km} \text {. } \\
\text { The landward extends of the } \\
\text { Pleistocene ridge is capped by } \\
\text { a well developed gypsum layer. }\end{array}$ & $3 \mathrm{~m}$ a.s.l \\
\hline
\end{tabular}


configuration and the prevailing hydrodynamic and climatic conditions were reconstructed based on the combination of the lithological interpretation, facies indication and stratigraphic correlation. Two submerged ridges were individuated and mapped in the field with regard to the high watermark by calculation of water depth in each outcrop. On the other hand, trenches were dug in various sites on the coastal plain in order to observe lithology and lateral facies variation of the Holocene deposits. Remote sensing drainage network analysis was used to investigate tracer fault because wadis that drain into the Gulf of Gabes borrowed trending faults normal to the coastline. The topography trend-surface was performed from SRTM90 data downloaded in May 2010 from USGS Seamless Data Distribution System (http://srtm.usgs. gov/data/obtainingdata.html), under TIFF format. Digital data were used to produce a Digital Elevation Model and many topographic profiles of the hinterland were completed from Global Mapper. The inter-relationship between hinterland topography, coastal morphology, hydrodynamic energy distribution and sedimentary facies transition between coastal environments has been largely investigated by a descriptive approach (table 1). Beach slope calculation was given through a bathymetric transverse profile ending at $5 \mathrm{~m}$ (closure depth). The coastal fringe was set at about $4 \mathrm{~km}$ from the shoreline. Changes in landscape features along this fringe were identified by 10 topographic profiles of the hinterland. We used a detailed description of each profile to extract spatial distribution of the major breaks in slope and transitions between lowland and highland. We define highland as plateau and hill and lowland as sebkha and salt pans.

\section{Results}

Major sea level fluctuations are associated with beach ridges whose shape and size depend on the antecedent topography and substrate slope (Mauz et al. 2013). Preservation of these ridges largely depends on wave activity and sediment budget.

\subsection{Palaeo-shorelines of the last interglacial MIS $5 e$}

We report here more details and specifications about the shape, morphology, altitude and lithofacies of the Pleistocene coastal deposits (MIS 5e ridge). These data will be compared with preexistent results determined by Jedoui et al. (2002). Around Gabes city, the Pleistocene deposits are preserved in small wadis outcrops and remain parallel to the present-day coastline. The Pleistocene deposits are presented by an elongated conglomeratic ridge separated from the coastline by $800 \mathrm{~m}$ wide swales (table 2). Dimensions and shapes of this ridge are characterized by low relief with gentle seaward and landward slopes (figure 2A). The top of the ridge culminates at $3 \mathrm{~m}$ a.s.l, where lithophagous pebbles are flattened and mixed with shell fragments, especially Strombus bubonius fossils. The rock fragments are diverse and the bioclastic elements are scattered in fine sandstone which consists of the matrix. At the north of Gabes city, the Pleistocene ridge became finer; it corresponds to an indurate sandstone (figure $2 \mathrm{~B}$ ). This ridge includes sedimentary structures which consists to planar stratifications containing shell fragments. These structures, placed at $3 \mathrm{~m}$ a.s.l, are interpreted as swash zone facies. This brutal change in
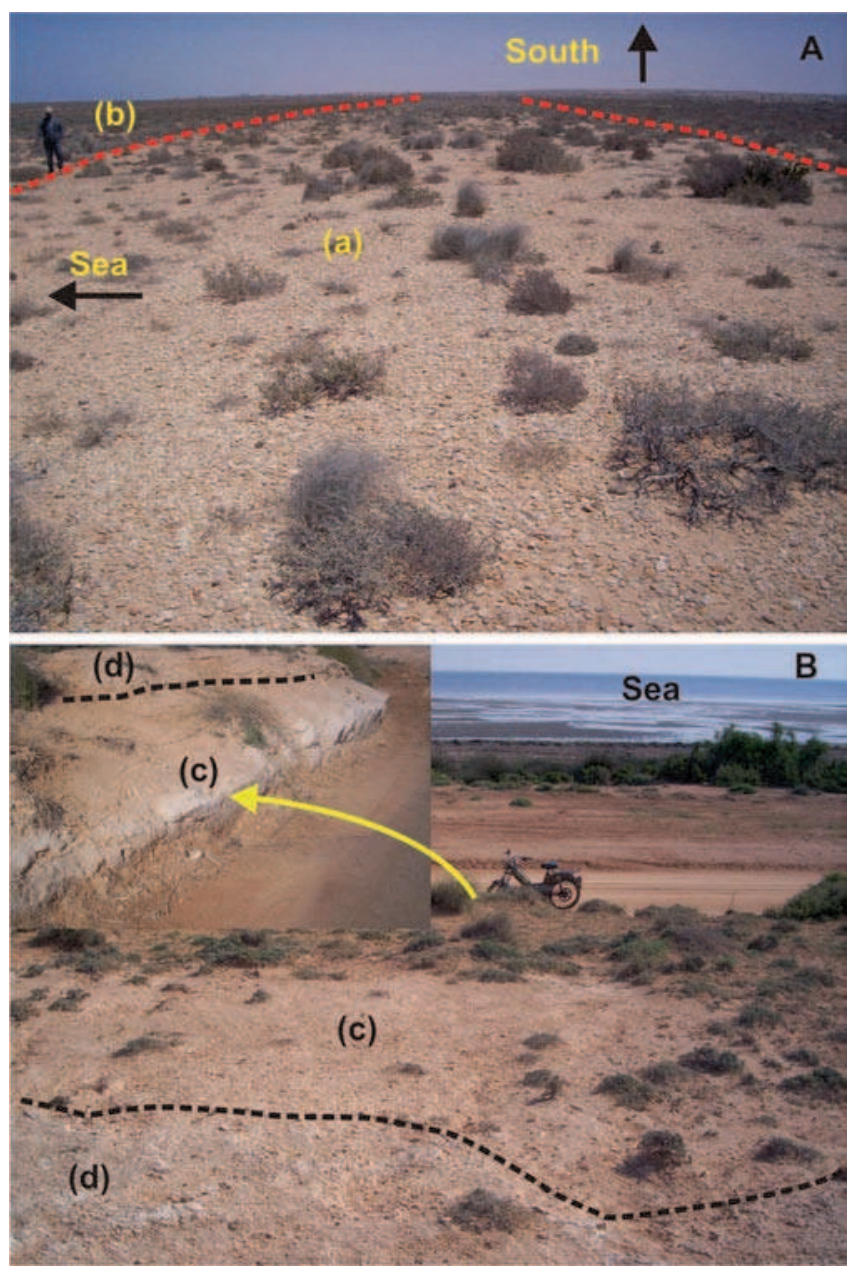

Figure 2. (A) MIS 5e ridge outcropping, between Wadi Zerkine and Wadi el Ferd, at few meters above sea level showing well flattened pebbles accumulation. The average dip is less than $2^{\circ}$ to seaward. From both sides of Pleistocene ridge, density of halophytic vegetation grows (a) conglomerate ridge, (b) sebkha. (B) Brutal change in the ridge facies (MIS 5e ridge) recorded in the northern side of Gabes city. (c) Indurate sandstone ridge composed by finer quartz sand, (d) Gypsum layer. 
the Pleistocene ridge facies (MIS 5e ridge) is mainly due to the sediment source which varies between the north and the south of Gabes city. At the north, sediment source, corresponding mainly to friable sandstone (Ben Ouezdou 1986) is very far from the coast. At the southern band, the coarser facies is supplied from the carbonate Mesozoic hills which are very close to the coast. Here, the wadis systems are well developed and fluvial discharges are activated. Near the wadi system, some parts of the MIS 5e ridge show a lateral continuity before being sharply cut by fluvial thalweg or covered by continental deposits like gypsum layer and aeolian sand. This ridge is detected in $1 \mathrm{~m}$ borehole and constitutes a very-poor sorted coarser facies, which is mixed with marine silty clay deposits (figure 3 ). Useries isotope analyses of numerous mollusc shells sampled from this sector show an age of $127.6 \pm 16$ ka (Jedoui et al. 2003). The MIS 5e ridge altitude fixed at about $3 \mathrm{~m}$ a.s.l in the studied area leads us to suppose that the Pleistocene deposits begin to approach normal altitude determined at Jerba Island ( $5 \mathrm{~m}$ a.s.l; Jedoui et al. 2002). This variation in the altitude around $2 \mathrm{~m}$ can be attributed to a local subsidence movement operated since the last 130 ka B.P. This relative stability of the northern edge of Jeffara during the late Pleistocene can be tolerated and can, therefore, be used as indicators of eustatic changes since the last interglacial.

\subsection{Onshore highstands MIS $5 c$ and MIS $5 a$}

A high precision echo-sounder was deployed during the field investigations at the Gulf basin where two separated marine ridges located at $\sim 19$ and $\sim 8 \mathrm{~m}$ b.s.l are identified (figure 4). These ridges belong to the present shoreline with a lateral extend of $50 \mathrm{~km}$ (figure 5). The relative altitude together with morpho-sedimentary analyses strongly support that the ridges located at $\sim 19$ and $\sim 8 \mathrm{~m}$ b.s.l are Pleistocene deposits and suggest an age of MIS 5c and MIS 5a, respectively. The sample collected from the submerged ridges shows mainly micritic accumulation in porous rock (figure 4). The remarkable similarity of facies data between sites allowed the lateral correlation of ridges. The stratigraphic correlation is reserved to the ridge situated at the same water depth. The younger ridge $(\sim 8 \mathrm{~m}$ b.s.l/MIS 5a) corresponds mainly to a biocalcarenite containing bioclasts and well preserved shells of Pholade (figure 4). Theses lamellibranches, largely distributed, can serve as environmental proxy where the intertidal sediments must be sufficiently hard before lamellibranches encrustations. The development of biocalcarenite in the beach ridges is the outcome of two phases: a high-energy phase (biocalcarenite deposition) followed by a low energy phase (muddy lower shoreface deposits). This succession of events could be compatible with a fast transgressive event. These phases are perturbed during flooding events where the coarse-grained materials are stacked in carbonate matrix. The southern side of Gabes city is characterized by siliciclastic ridges. The petrographic analysis reveals mainly pebbles and fragments of older limestones. Here the conglomeratic facies is abundant and, in thin-section, the proportion of peloidal micrite and well-rounded grains is higher (table 3 ). The older ridge ( $\sim 19 \mathrm{~m}$ b.s.l/MIS $5 \mathrm{c})$ consists mainly of coarse-grained material with rounded pebbles up to $2 \mathrm{~cm}$ in diameter (table 4). At Zerkine site,

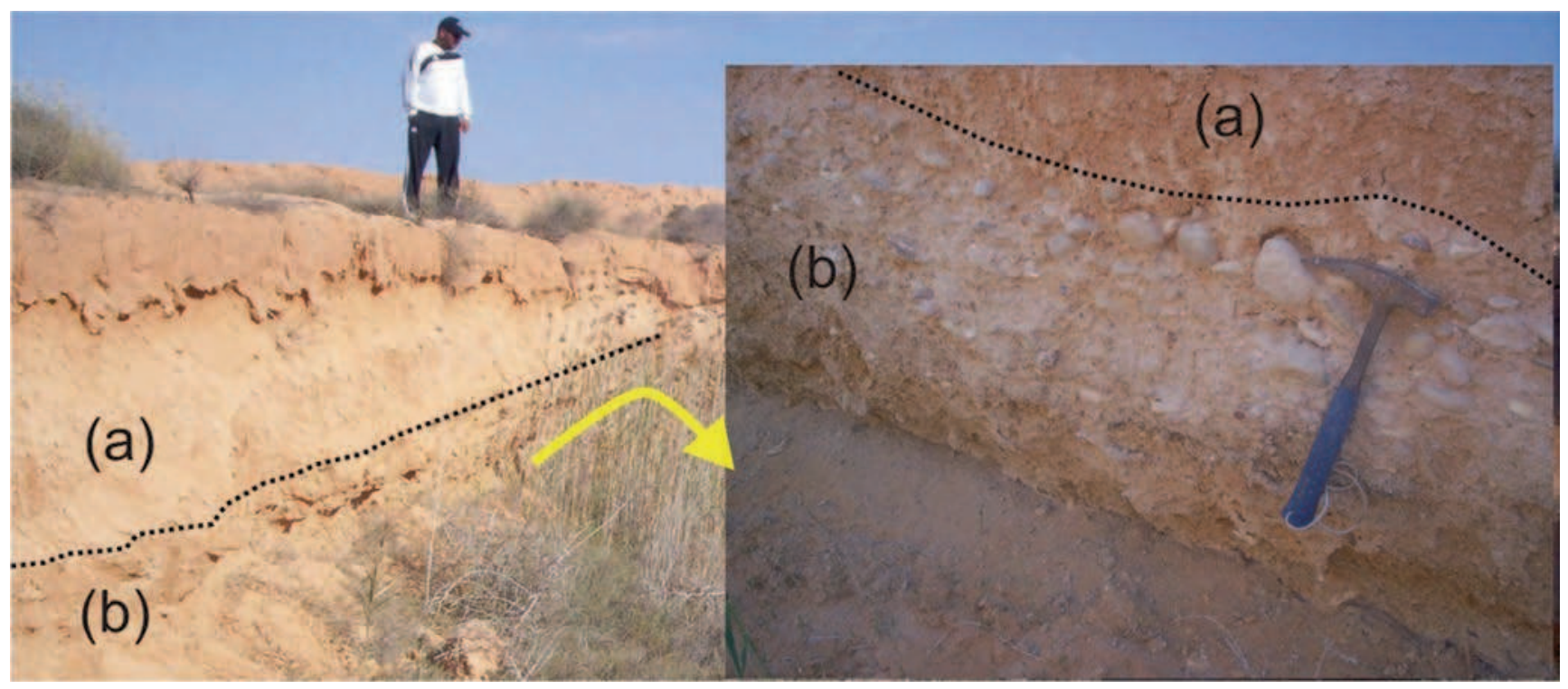

Figure 3. Pleistocene ridge (MIS 5e) detected in $1 \mathrm{~m}$ borehole: (a) red silt rich in gypsum and (b) conglomerate ridge. 


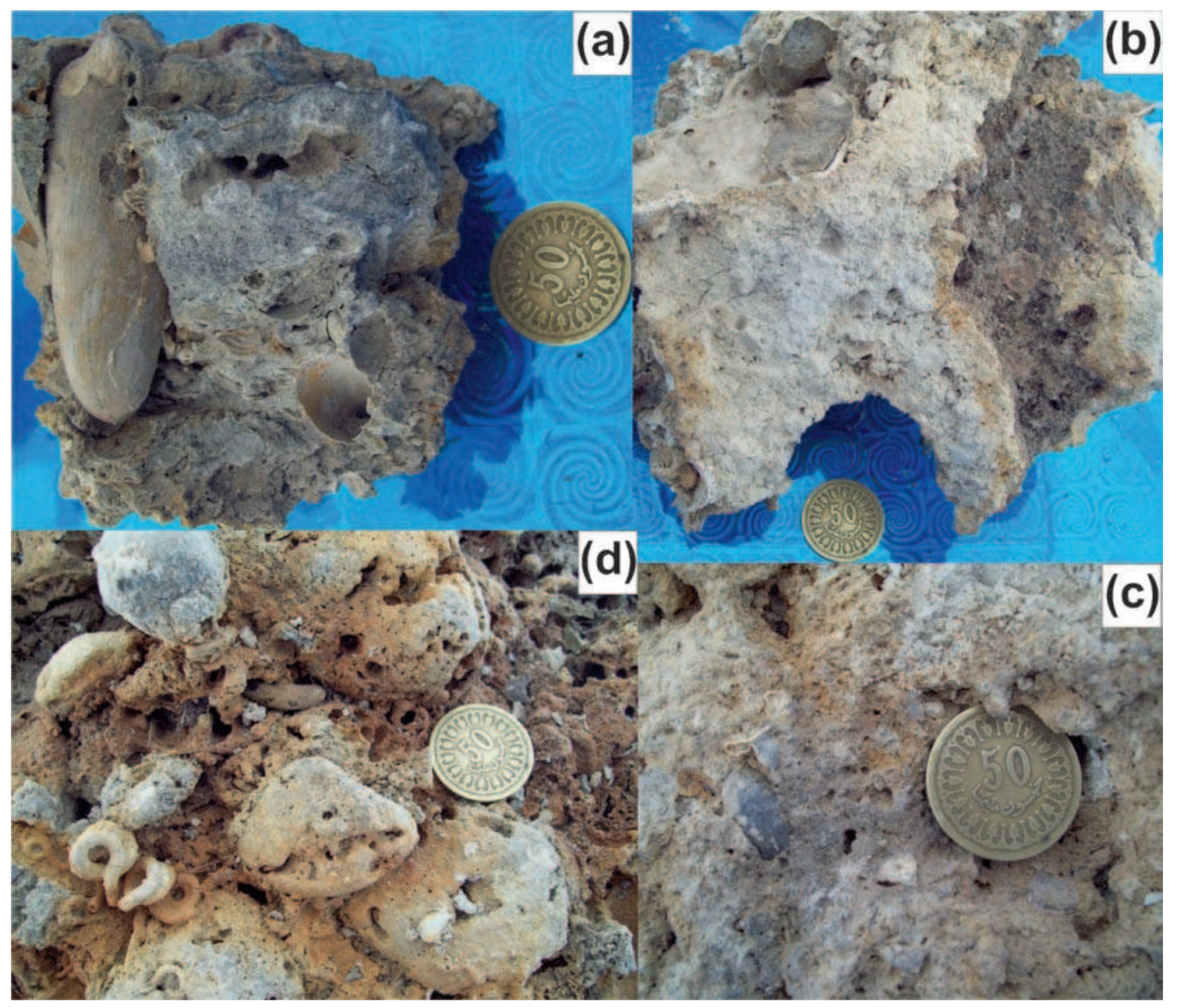

Figure 4. Wide range of facies category in the submerged Pleistocene ridges suggesting diverse environment deposits (a) Zarat $18 \mathrm{~m}$ b.s.l: (MIS 5c ridge, southern Gabe city) incrusted Pholad shell in bioclastic sandstone suggesting highenergy deposits. (b) Ghannouche $8 \mathrm{~m}$ b.s.l: (MIS 5a ridge, northern Gabes city) muddy bioclastic limestone indicating calm deep-water environment. (c) Zerkine 20 m b.s.l: (MIS 5c ridge, southern Gabes city) limestone facies with sparse pebbles invoking calm environment receiving fluvial discharge from neighbouring wadis inlet. (d) Kettana $8 \mathrm{~m}$ b.s.l: (MIS 5a ridge, southern Gabes city) lithophagous pebbles with incrusted serpulids suggesting agitated conditions in shallow marine environment. (Sr: Serpulids, Mu: Mud limestone, Bi: Bioclasts, Bu: Burrows, Pe: Pebbles, Ph: Pholad).

this ridge extends several hundred meters seaward and show facies changes from the shoreface to the foreshore deposits. The ridge facies starts by indurate fine sandstone and ends with calcareous facies scattered by rounded pebbles (figure 4). The relative increase of pebbles and limestone fragments included in the Pleistocene ridges show that the southern side of Gabes city is dominated by the fluvial discharge.

\subsection{Palaeo-shorelines of the post-glacial marine transgression}

Two distinctive classes of Holocene beach ridges can be discerned between the northern and southern sides of Gabes city. This distinction is due to the lateral variation of the gradient substrate between the north (Trab el Makhadha), where the slope is about $1.13 \%$ and the south bands (Chat
Hamrouni), where the slope is about $0.59 \%$. Going further south (towards Zarat), the slope is softer $(0.38 \%)$. Lateral slope switch has a critical role controlling size and dimension of ridge (Roy et al. 1994). In Trab el Makhadha, relatively substrates steepen, coastal features are more developed: the dune belt is approximately $100-200 \mathrm{~m}$ wide and varies in elevation from 5 to $7 \mathrm{~m}$ a.s.l. Ridge patterns shown on air photos are quite regular and are aligned sub-parallel to the present coastline. The Holocene marine deposits, attributed to the mid-Holocene emergence $(6600 \pm 100){ }^{14} \mathrm{C}$ years (Jedoui et al. 1998; Morhange and Pirazzoli 2005), are covered by $0.8 \mathrm{~m}$ of sand. These deposits are made up of well-sorted medium-grained sand $(\mathrm{Mz}=1.8$ and So $=0.3)$. The latter consists mainly of quartz, which contains rounded pebbles and shells. However, the southern side, where gradient substrates are not too steep, reveals minor 


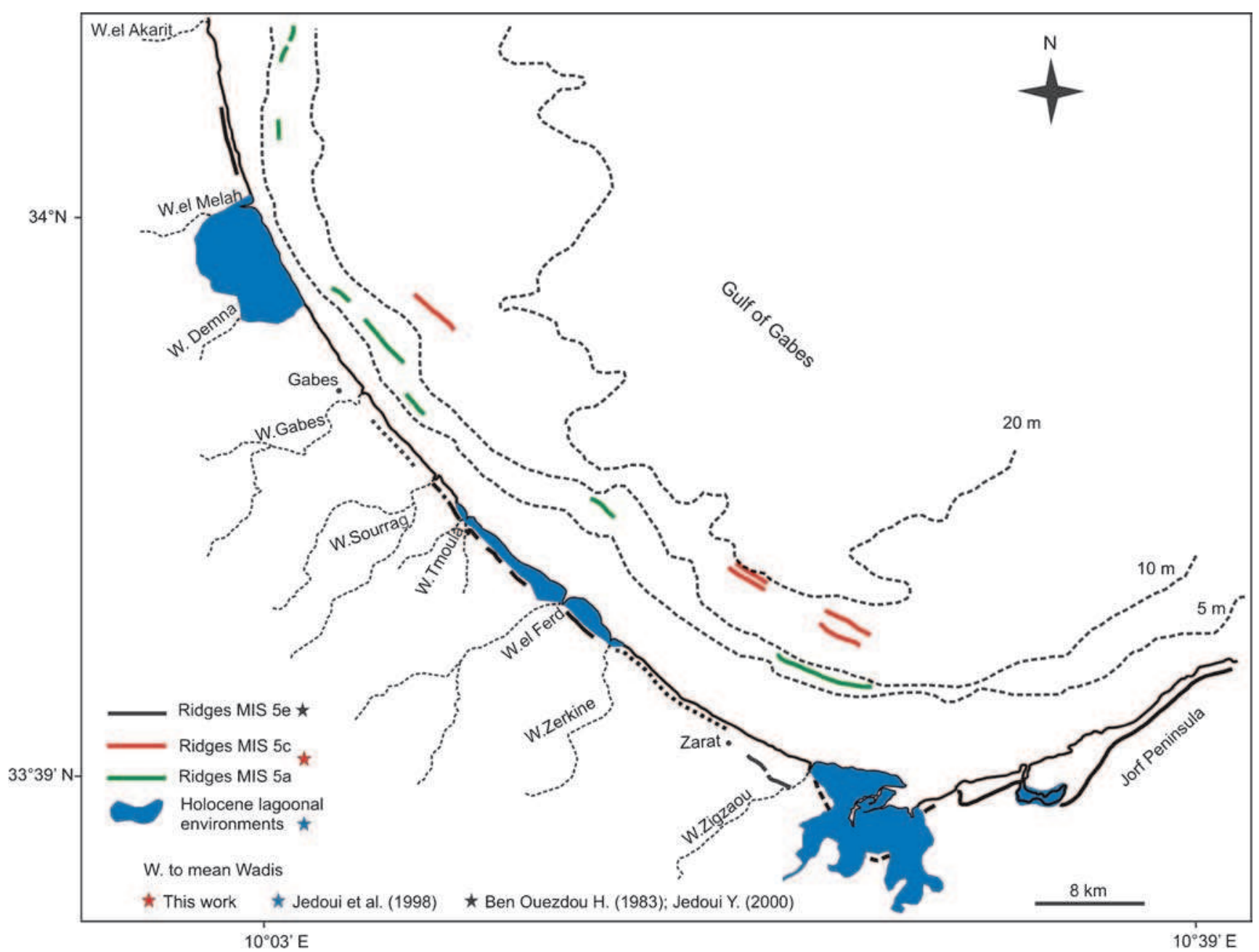

Figure 5. Disposition of the Pleistocene ridges along the study area (MIS 5e; Ben Ouezdou 1983; Jedoui 2000, MIS 5c and MIS $5 \mathrm{a}$; this work).

Table 3. Petrographic descriptions of the Pleistocene coast (substage MIS 5a) along the Gabes basin.

\begin{tabular}{|c|c|c|c|}
\hline Sites & Facies description & Petrographic characteristics & Seafloor \\
\hline Bsissi & $\begin{array}{l}\text { Biocalcarenite containing abundant } \\
\text { bioclasts. Abundant serpulids and } \\
\text { calcareous concretion. }\end{array}$ & $\begin{array}{l}\text { Micritic accumulations are in association } \\
\text { with spiral arrangement of cortical tubes } \\
\text { (rich in fossil debris). }\end{array}$ & $8 \mathrm{~m} \pm 1$ b.s.l \\
\hline Ghannouche & $\begin{array}{l}\text { Biocalcarenite composed of shell } \\
\text { fragments. Abundant burrows } \\
\text { containing shells of pholade and } \\
\text { cardium. Precipitation of mud } \\
\text { limestone suggests sedimentary } \\
\text { accumulation in subtidal zone. }\end{array}$ & $\begin{array}{l}\text { Micritic accumulations are in association } \\
\text { with benthic foraminifers. Sometimes, the } \\
\text { shells are pretty well preserved. Presence } \\
\text { of ostracods suggesting low energy } \\
\text { conditions. }\end{array}$ & $9 \mathrm{~m} \pm 1$ b.s.l \\
\hline Teboulbou & $\begin{array}{l}\text { Quartz sandstone containing pebbles. } \\
\text { Clasts consist of Mesozoic limestone } \\
\text { fragments. }\end{array}$ & $\begin{array}{l}\text { Individual quartz grains are held together } \\
\text { with calcitic cement. Presence of benthic } \\
\text { foraminifers which are reworked. }\end{array}$ & $8 \mathrm{~m} \pm 1$ b.s.l \\
\hline Kettana & $\begin{array}{l}\text { Very coarse grained conglomerate made } \\
\text { of rounded pebbles up to } 3 \mathrm{~cm} \text { in diameter. } \\
\text { Pebbles are incrusted by serpulids } \\
\text { calcareous concretion. }\end{array}$ & $\begin{array}{l}\text { Well rounded cobbles cemented with calcitic } \\
\text { cement. This coarser facies suggests high } \\
\text { energy conditions. }\end{array}$ & $9 \mathrm{~m} \pm 1$ b.s.l \\
\hline Zarat & $\begin{array}{l}\text { Fine grained bioclastic quartz rich sand. } \\
\text { Sandstone is not sufficiently hard. }\end{array}$ & $\begin{array}{l}\text { Individual quartz grains are held together } \\
\text { with a calcitic cement. }\end{array}$ & $8 \mathrm{~m} \pm 1$ b.s.l \\
\hline
\end{tabular}


Table 4. Petrographic analysis of the Pleistocene coast (substage MIS 5c) along the Gabes Basin.

\begin{tabular}{|c|c|c|c|}
\hline Sites & Facies description & Petrographic characteristics & Seafloor \\
\hline \multirow[t]{2}{*}{ Zerkine } & Biocalcarenite & $\begin{array}{l}\text { Calcareous mudstone characterized by very } \\
\text { poor faunal content. }\end{array}$ & $20 \mathrm{~m} \pm$ 1b.s.l \\
\hline & Sand stone & $\begin{array}{l}\text { Internal structural show alternating bioclastic level } \\
\text { with medium quartz sand. }\end{array}$ & $18 \mathrm{~m} \pm 1$ b.s.l \\
\hline Zarat & $\begin{array}{l}\text { Very coarse grained } \\
\text { material with rounded } \\
\text { pebbles up to } 2 \mathrm{~cm} \\
\text { in diameter }\end{array}$ & $\begin{array}{l}\text { The coarse grained intervals have extremely } \\
\text { abundant biogenic material in a muddy } \\
\text { sand matrix. }\end{array}$ & $18 \mathrm{~m} \pm 1$ b.s.l \\
\hline
\end{tabular}

sandy-ridge as sand sheet forms. A flared ridge pattern is quite variable in height and width, and shape is reduced. These small barriers consist mainly of aeolian fine-grained sediment member. Sediment grain size, revealed from trenches, is very fine $(\mathrm{Mz}=2.9)$ and contains valve of lamellibranches in living position and small size shells of gastropods (cerithiidae). The amount of the silt fraction reaches $8 \%$ indicating a protected area which corresponds to an extensive lagoonal environment (figure 5).

\subsection{Events and seasons evolution}

The coastline of the Gulf of Gabes is one of the longest and most diverse (including sea cliffs, sandy beaches and tidal flat) in Tunisia. Three classes of coastal systems are recognized at the base of the coastal morphology variety associated with the hydrodynamic processes (table 1). The altitudes of the hinterland topography range from approximately $40 \mathrm{~m}$ a.s.l. at Zarat (figures 6, 7) in the south to $4.5 \mathrm{~m}$ a.s.l at Ouïnet in the north of the study area. We reveal that antecedent hinterland topography interplays with hydrodynamic processes such that morphological variety of the coast is enhanced (table 1).

\subsubsection{Sea cliffs}

The sea cliffs are formed when the hinterland topography corresponds to a high plateau. It remains at a high elevation ranging between 20 and $30 \mathrm{~m}$ a.m.s.l (figure 7a, c, i, j). These high plateaus, composed of silt-clay and gypsum, are incised by long and narrow wadis, probably presenting entrenchment of a pre-existing drainage network, where both sides are flanked by ancient fluvial terraces. Generally, cliffs are fronted by a gently sloping muddy shore platform. Wave activity is reduced; the intertidal zone is mostly occupied by tidal channels parallel to the coastline favouring amplification of the tidal current during flood period. Morphologic observation of the shoreline shows that the seasonal evolution is punctuated by a positive sedimentary budget. The prevailing low energy conditions have favoured, since 1980's, sediment accumulations. The genesis of a small sandy ridge and the growth of stromatolites on the upper part of the shore platform suggest an active transport onshore (figure 8a, b). The small ridge, constituted mainly by quartz sand invokes terrigenous material origin supplied during inundation events through joints and cracks. The dismantling of the immersed ridge situated below present sea level seems to be the second sedimentary source. However, the effect of storm event, e.g., storm surging at the beginning of February 2014, manifests by the net erosion of the cliff.

\subsubsection{Sandy coasts}

Sandy coasts are made at the border of structural depressions like graben of Oü̈net and graben of Gabes (figure 7b,d). The shape and dimension of the beach ridge is controlled by the antecedent topography. The morphologic observation reveals that when the hinterland consists of a sebkha domain, the available space to support sandy accumulations is enhanced. However, the flared sandy ridge occupies ancient flattened platform advancing former cliff. The beaches, situated at the northern side of Gabes city are characterized by a highly slope angle $(1.13 \%)$. These beaches are more exposed to the wave and current processes, where waves transport sand from offshore sources, such as deep-water bars or ebb-tidal shoals, to the shoreline and onto the dry beach. These hydrosedimentary processes are materialized by the deposition of a thick layer of lamellibranche shells onto the dry beach. The N-S dominant longshore drifts, formed during NE prevailing sea swell, move sediment from the eroding headland to the sandy coasts. Sediment is also redistributed by westerly wind which suppresses wave action and leads to the shoreface accretion. The outcome is a well developed berm with rhythmic features. The beach step is located at the base of the beach face around the low water mark, where a band of cobbles, shells and algae 


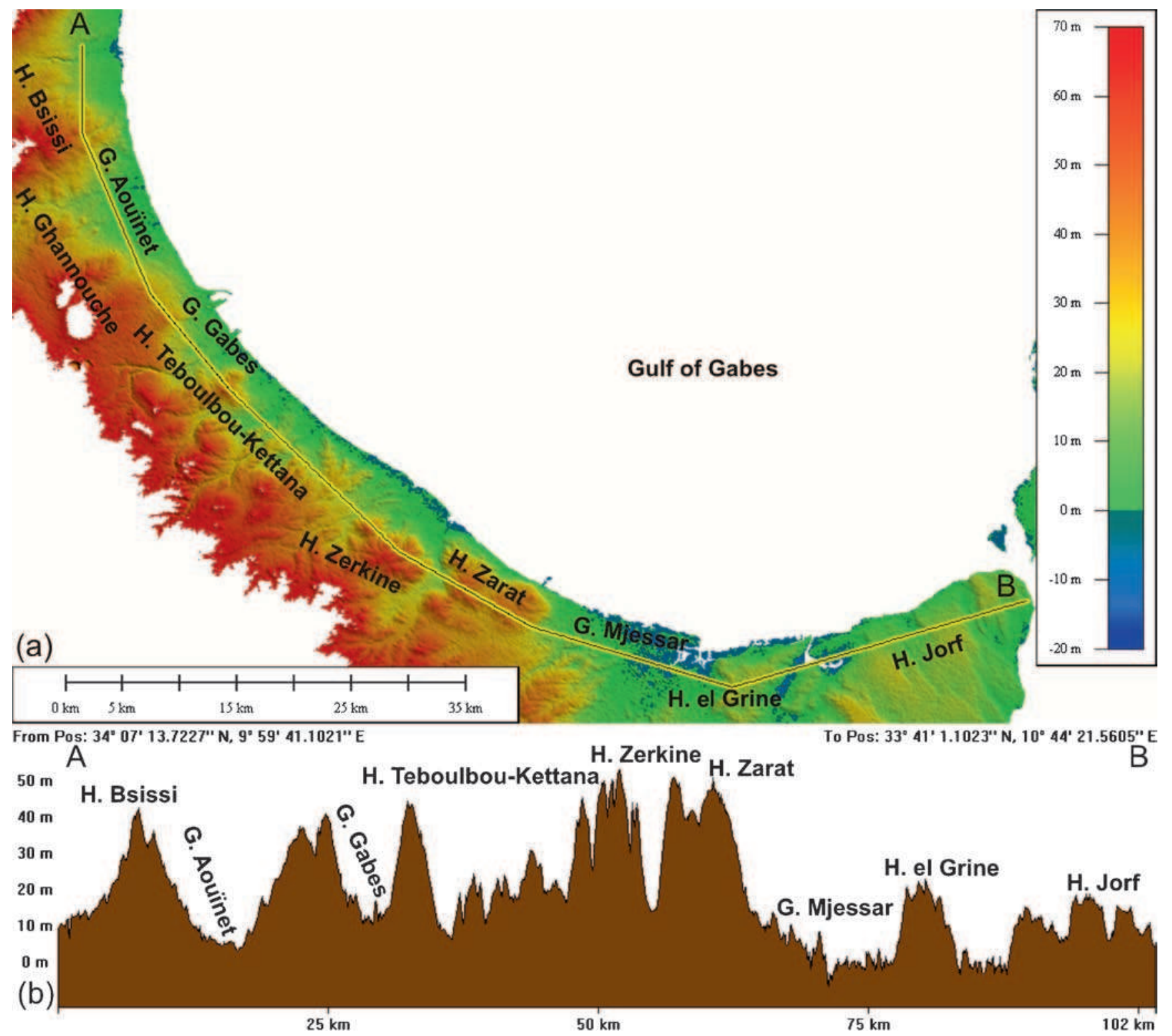

Figure 6. (a) SRTM data illustrating major geomorphic subdivisions, which correspond to the alternation of horsts and grabens along the Jeffara edge basin (Horst and graben are referred to Ben Baccar 1982). (b) NW-SE profile along the study area showing that the distribution of relief elements is in direct relationship to the geological structure of the area. This profile crossed fringe coast at approximately $4 \mathrm{~km}$ inland.

debris is present. Immediately seaward of the step, the sediments are usually a fine marking transition to the foreshore, with a steep profile typical of reflective beaches. The seasonal evolution of the beaches is marked by a progradational trend. This tendency, sensitive since 1980's, is marked by sedimentary accumulation and total filling of tidal inlet. However, a storm event, which generates sea surface pile-up, engenders considerable erosion across the beach profile (figure 8c, d). At the south of Gabes city, beaches are moderately exposed to the NE prevailing wave. The hinterland topography corresponds to the horst of TeboulbouZarat (figure $7 \mathrm{e}, \mathrm{f}, \mathrm{g}$ ). This plateau is characterized by rough modelling of valley and ranges of hills strongly dissected by hydrographic network (figure 6). The available space potential to support sediment accumulations is limited. The lithological character of this plateau consists of a conglomerate construction covered by thick level of gypsum. The eastern edge of the hinterland consists of the graben of Chat Hamrouni, where coastal salt pans occur and range from about $4 \mathrm{~km}$ for Chat Hjel, $1 \mathrm{~km}$ for Chat Hamrouni and only $0.5 \mathrm{~km}$ for Zarat (figure 6). In these broad flat salt pans, sediments depend on local provenance: horsts are often the predominant source into the down-dropped graben through an extensive wadis system, which intersects coastal plain and acts as seasonal run-off conduits. Morphologic survey combined to images satellite 
From Pos: 9.9878458219, 34.0525249211

To Pos: 10.0311961157, 34.0525249211

(a) $\begin{array}{r}40 \mathrm{~m} \\ 15 \mathrm{~m}\end{array}$ From Pos: 10.0041021821, 33.9893057425 $\quad 1.5 \mathrm{~km} \quad$ 2.0 km $\quad \begin{array}{ll}2.5 \mathrm{~km} & \text { To Pos: 10.0465493448, 33.9992401849 }\end{array}$

(b) $30 \mathrm{~m}$ m $15 \mathrm{~m}$

\begin{tabular}{cccccccc}
\hline $0.5 \mathrm{~km}$ & $1.0 \mathrm{~km}$ & $1.5 \mathrm{~km}$ & $2.0 \mathrm{~km}$ & $2.5 \mathrm{~km}$ & $3.0 \mathrm{~km}$ & $3.5 \mathrm{~km}$ & $4.07 \mathrm{~km}$
\end{tabular}

From Pos: $10.0402274270,33.9233771706 \quad$ To Pos: 10.0799651963, 33.9378272686

(c) $30 \mathrm{~m}$ m: 30 :

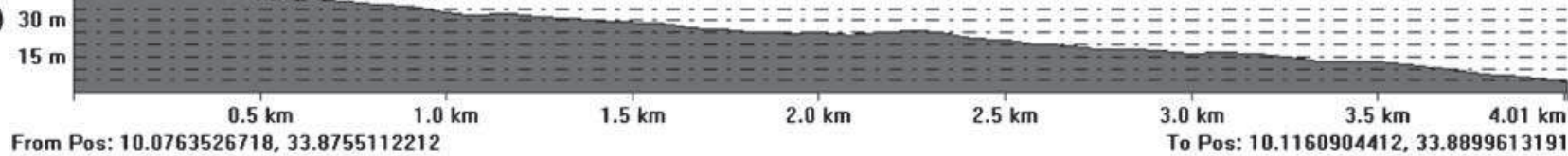

(d) $45 \mathrm{~m}$ m $\mathrm{m}:$ :

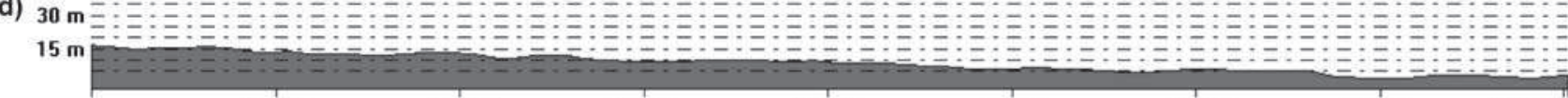

\begin{tabular}{lllllllll}
\hline $0.5 \mathrm{~km}$ & $1.0 \mathrm{~km}$ & $1.5 \mathrm{~km}$ & $2.0 \mathrm{~km}$ & $2.5 \mathrm{~km}$ & $3.0 \mathrm{~km}$ & $3.5 \mathrm{~km}$ & $4.01 \mathrm{~km}$
\end{tabular}
From Pos: 10.0989309499, 33.8475141564 $\quad$ To Pos: 10.1341530636, 33.8682861722

(e) $30 \mathrm{~m}$ From Pos: 10.2524632406, 33.7237851927 $\quad 1.5 \mathrm{~km} \quad$ To Pos: 10.2813634365, 33.7526853886

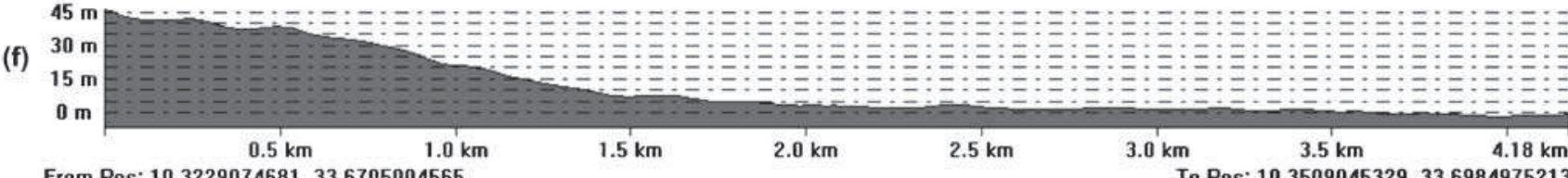

(g) $45 \mathrm{~m}-\cdot-\mathrm{n}$ )

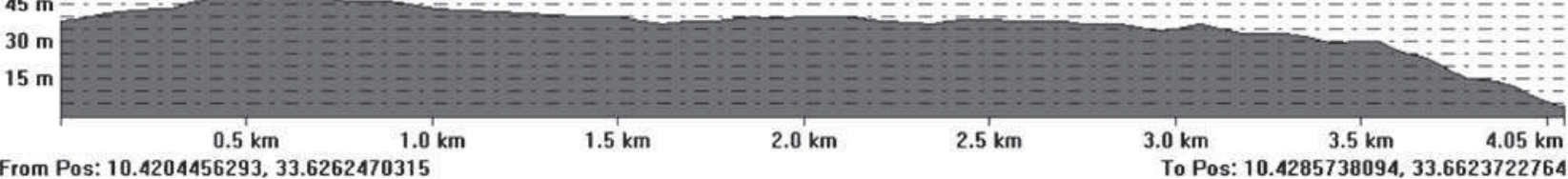
From Pos: 10.4204456293, 33.6262470315

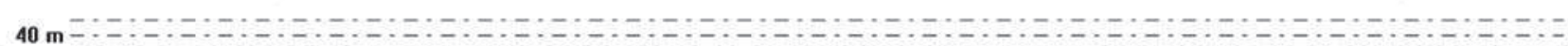

(h) $20 \mathrm{~m}=: \mathrm{a}: \mathrm{a}$ $0 \mathrm{~m}$ m

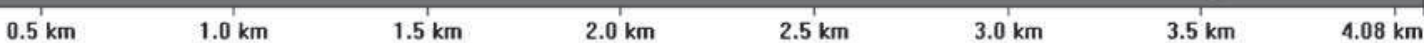

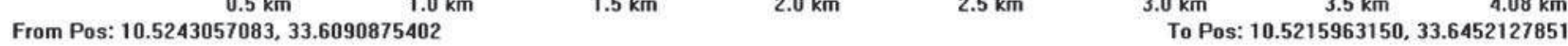

(i) $40 \mathrm{~m}-100$ $20 \mathrm{~m}=$ \begin{tabular}{rlllllll}
\hline $0.5 \mathrm{~km}$ & $1.0 \mathrm{~km}$ & $1.5 \mathrm{~km}$ & $2.0 \mathrm{~km}$ & $2.5 \mathrm{~km}$ & $3.0 \mathrm{~km}$ & $3.5 \mathrm{~km}$ & $4.01 \mathrm{~km}$
\end{tabular} From Pos: 10.7175757684, 33.6714035876 $\quad 1.5 \mathrm{~km} \quad$ To Pos: 10.6986100149, 33.7048194391

(j) $30 \mathrm{~m}$

Figure 7. Topographic profiles along the studied coast showing a contrast in spatial evolution of the hinterland. Point co-ordinates are listed at each profile (From Pos: From Position; To Pos: To Position). Hinterland topography (a) Bsissi, (b) Ouïnet, (c) Ghannouche, (d) Gabes, (e) Teboulbou, (f) Zerkine, (g) Zarat, (h) Mejessar, (i) Grine, and (j) Jorf.

data show that the southern band of Gabes city is marked by the genesis of a linear ridge formed since 1980's. Beaches are dissipative and tend to be steeper with a gentle slope and wide low tide terrace which may be up to $200 \mathrm{~m}$. The sediment is fine and wave heights average between 0.25 and 

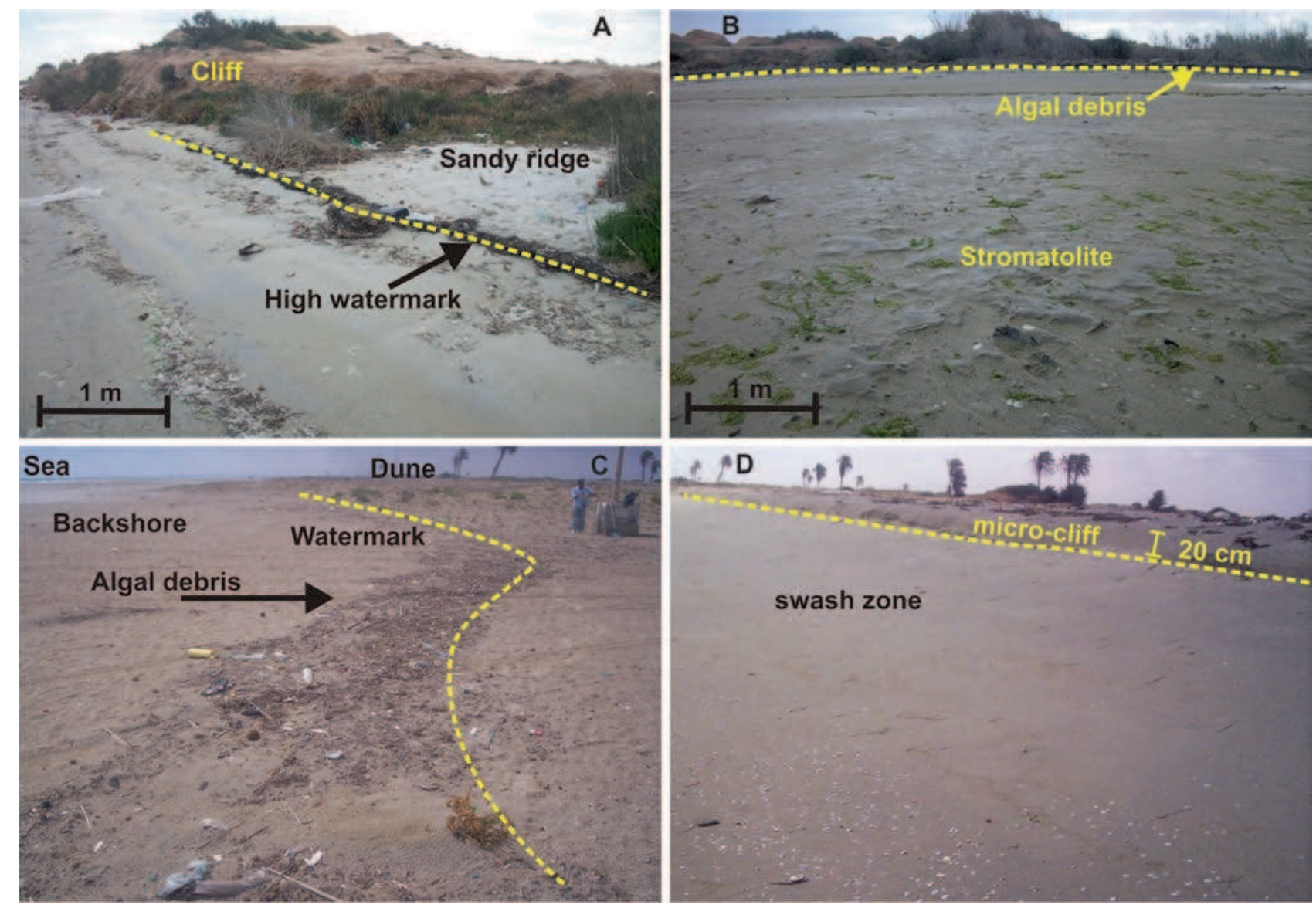

Figure 8. Bsissi region marked by recent sedimentary accumulation (a) sandy ridge, (b) stromatolite. Erosion action of the storm on the beach of Trab el Makhadha, (c) inundated backshore, and (d) erosion of the upper swash zone.

$0.5 \mathrm{~m}$. Morpho-sedimentary dynamics are strongly driven by littoral drift action. A sandy accumulation has sheltered, in the backshore, salt marshes domains with a branched network of tidal channels.

\subsubsection{Tidal flat}

Here the hinterland topography corresponds to a graben (Sebkha Mjessar, figure $7 \mathrm{~h}$ ), which is characterized by the flatness of field. It is around 13 $\mathrm{km}$ long and $6 \mathrm{~km}$ wide and receives as many as three wadis with a large meander: such as Wadi Mjessar. Graben Mjessar is situated at the junction between horst Zarat and horst Jorf, which is located at the eastern side of the study area. This transitional landscape which corresponds to a structural depression is characterized by sand dunes (lunettes) derived from deflated alluvium channel. Greater quantities of aeolian sand reach the depositional plain through structural aeolian corridor dressed perpendicularly to the coastline. The altimetry of this graben (Sebkha Mjessar) is presently below high tide level leading inland seawater penetration through tidal channel, while its extant vegetation is mostly halophytic. This section of coastline, the most sheltered site, represents a large embayment where interaction between the waves and the bottom is limited and phenomena such as shoaling, refraction, wave breaking and reforming are of minor importance. But tidal energy was dominated and manifested by a well developed network of tidal channel, whereas the most featured one was Wadi Choaba bounded by dense cover of marshes. Muddy progradation, developed since 1980's, is expressed by salt marsh expansion. A decimetre slope height notched by active creeks underlines the passage towards slikke, which is characterized by local depressions and may be often inundated by sea water.

\section{Discussion}

\subsection{Coastal morphology and hinterland topography}

These morphodynamic systems are explored to explain the evolution of the studied coast at different scales ranging from the event to the geological scale. In global and regional scales, coastal 


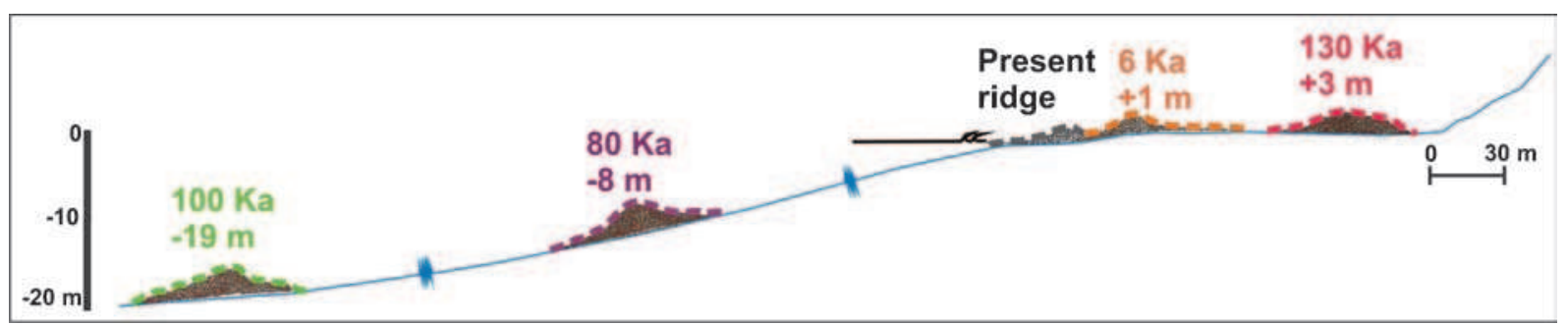

Figure 9. Interaction between sediment availability and sea level change since 130 ka is characterized by a forced regressive beach-ridges plain.

morphology often correlates closely with the inherited characteristics that give the present-day coast its distinctive appearance (Inman and Nordstrom 1971; Carter 1992; Finkl 2004). Often, we consider that coastal morphology is the interplay between water and sand under the influence of tides, wind and waves. But we neglect the underlying geological structure and rocks. From the present study, it has been inferred that major tectonic lineaments appear to control topography features and have a great influence on the development of the modern morphology. Many topographic profiles which broaden hinterland showed that from $4 \mathrm{~km}$ to the shoreline, the topographic hinterland ranges from $10 \mathrm{~m}$ a.s.l. at Mjessar wetlands to $50 \mathrm{~m}$ a.s.l. at el Bsissi upland. On the basis of the major break slope already established, we found a succession of grabens like Ouïnet, Gabes, Chat Hamrouni and Mjessar, which alternate with horsts Bsissi, Ghannouche, Teboulbou-Zarat and Jorf (figure 6). The topographic setting is somehow influenced by lithology. At Bsissi and Jorf sea cliffs, where siltclayey continental deposits extensively outcrop, topography is smoother than towards KettanaZarat, where Mio-Plio-Quaternary formation, mainly conglomeratic, gives rise to a more incised relief. Whereas, the predominant landscape features along the hinterland are series of hillocks most of which have been incised by drainage network and surrounded by fluvial plain. Geomorphologic observations provide that depositional features are more observed in the grabens boundary where areas are fronted by deep shoreface. These features vary widely in their morphology adapted and amplified by hydrodynamic factors which sort appropriate sediments and materials. Waves, currents and tides rework the sediment to create shoreface morphology that attempts to attain steady-state conditions.

\subsection{Palaeodynamic changes}

The Mediterranean Sea becomes a key site for understanding the connection between high and mid-latitude climatic changes in the northern hemisphere (Bardaji et al. 2009). Pleistocene ridges represent a sensitive paleoclimatic record of sealevel changes and hydrological regime. Along the Tunisian coasts, carbonate sediments are used as a proxy of negligible fluvial discharge and warmarid zones during the late Pleistocene (Mauz et al. 2012). Petrographic characteristics of Pleistocene ridges, provided from thin sections, show abundance of ooids and peloids. The MIS 5e ridge forms generally very poor-sorted gravelly shoreface with well flattened and rounded pebbles lying few meters above modern coast. Generally, these ridges are devoid of sedimentary structure but include gastropods and bivalves and are significantly different from actual shoreface, which shows much finer sediments. Shape of the flattened lithophagous pebbles shows that prevalent tidal range and marine processes (uprush and backwash) must be significant to build up conglomerate ridges at the high water level. During the late Pleistocene, rhythmic flood periods occurred at about 95-100 ka and 130-150 ka (Causse et al. 2003). These flood events, carrying clasts (pebbles and cobbles) from the carbonate Mesozoic hills, are in phase with the Pleistocene transgressive events. Analyses of organic-rich layers in the western Mediterranean basin suggest an increase in storminess and rainfall during warmer substages MIS 5e, MIS 5c and MIS 5a (Bardaji et al. 2009). In this scenario, sediment mass movement towards the sea under conditions of sea level fall explain the genesis of gravel ridges. In general terms, the fluvial discharges are dispersed by wave reworking, where coarse material would be added to the shoreface and incorporated in forced regressive ridge. The data supporting this idea are the altitude of the Pleistocene ridge ranging between +3 and +5 $\mathrm{m}$ a.s.l and the sedimentary facies which is characterized by coarser materials. The shoreface deposits pass into aeolian sediments representing the high sea level stand, following the transgression (Mauz et al. 2009; Elmejdoub et al. 2011; Mauz et al. 2013). The aeolian system can be formed during rapid sea-level fall which exposes continental shelf to the wind action (Andreucci et al. 2010). The powerful wind action carries marine sediments faraway from the palaeo-shoreline (Andreucci et al. 
2010). In other coastal zones, tectonic activity is the main factor controlling preservation of the marine sedimentary deposits during Quaternary period. In the northeastern coast of Tunisia (Cap Bon peninsula), progressive uplift movement has favoured preservation of three marine platforms showing mixed carbonate and siliciclastic sediments of middle to late Pleistocene (Elmejdoub and Jedoui 2009). As shown previously, the tectonic movement since the last interglacial is reduced and the Pleistocene data from the gulf of Gabes (southern Tunisia) is assumed to be largely free from significant vertical tectonic movement. The altitude of Pleistocene ridges is comparable to those of contemporaneous marine deposits found in many tectonically stable areas of the world such as in Bermuda and Bahamas (Jedoui et al. 2003). These ridges can therefore be used as indicators of eustatic changes during the last interglacial. Thus, we consider that the southern part of the Tunisian coast remained relatively stable, with no significant tectonic activity for at least the last 130 ka. Two subaqueous ridges are situated at -19 and $-8 \mathrm{~m}$ b.s.l. These coastal ridges are attributed respectively to the MIS 5c and MIS 5a. However, Dorale et al. (2010) suggest that the MIS 5a sea-level highstand was reached $1 \mathrm{~m}$ a.s.l in the western Mediterranean. Tectonic activity which occurred during the lower and middle Pleistocene (Goy and Zazo 1989; Dabrio et al. 2011) seems to be responsible for the mentioned highstand in the region. In the Cap Bon peninsula, two aeolianites member corresponding to MIS 5c and MIS 5a are dated using optical method (Elmejdoub et al. 2011). The marine sediments that are related to the aeolianite member, are now situated under modern sea level (Elmejdoub et al. 2011). This configuration scheme is in phase with the Spanish Mediterranean coast and other neighbouring countries such us Italy (Bardaji et al. 2009).

\section{Conclusion}

The coastal palaeogeomorphology was shaped similarly to its present shape with succession of beaches and sea cliffs. Morphological changes on the foreshore and shoreface domains during transgressive periods (MIS 5e, MIS 5c, MIS 5a, mid-Holocene highstand and actual period) have been recorded in a forced regressive beach-ridges plain. Five beachridges were individuated and mapped in the field which are formed around $5 \mathrm{~m}$ a.s.l/120 ka, $-19 \mathrm{~m}$ b.s.l/100 ka, $-8 \mathrm{~m}$ b.s.l/80 ka, $2 \mathrm{~m}$ a.s.l/6 ka and actual ridge (figure 9). The stability of bedrock slopes existing on this coast section at different Quaternary sea levels have favoured deposition of sediment sequences depending mainly to the sediment origins.

- During warmer substages (MIS 5e, MIS 5c and MIS 5a), fluvial discharges are active. Pleistocene ridges are commonly formed with coarser sediments.

- The interplay between local topographic setting and sea level emergence associated with hydrodynamic processes, allowed the formation of lagoonal environments behind sandy ridges running roughly parallel to the coastline during the mid-Holocene RSL high stand. Modern clastic deposits fill this environment.

- Present period, marked by low discharge of sediments to the coastal zone, has favoured sedimentary carbonate deposits where abundant shells and shell fragments are accumulated. Hydrosedimentary processes interplay antecedent topography such that morphological diversity of the coast is amplified. These features range from extensive beach-ridges, plain to prograded tidal flat, showing sandy barrier emergence and marshes expansion.

\section{Acknowledgements}

The authors are grateful to the Editor, D Shankar and an anonymous reviewer for their critical and constructive reviews. This work was carried out within the research unit of Applied Hydrosciences in the Higher Institute of Water Sciences and Technics of Gabes.

\section{References}

Abdennadher J and Boukthir M 2006 Numerical simulation of the barotropic tides in the Tunisian shelf and the strait of Sicily; J. Mar. Syst. 63 162-182.

Amari A 1984 Contribution à la connaissance hydrologique et sédimentologique de la plate forme des kerkena; Thèse $3^{\text {ème }}$ cycle Université de Tunis, Facultés des sciences, $251 p$.

Anzidei M, Antonioli F, Lambeck K, Benini A, Soussi M and Lakhdar R 2011 New insights on the relative sea level change during Holocene along the coasts of Tunisia and western Libya from archaeological and geomorphological markers; Quat. Int. 232 5-12.

Andreucci S, Clemmensen L B and Pascucci V 2010 Transgressive dune formation along a cliffed coast at $75 \mathrm{ka}$ in Sardinia, western Mediterranean: A record of sealevel fall and increased windiness; Terra Nova, doi: 10.1111/j.1365-3121.2010.00971.

Arz H W, Lamy F, Ganopolski A, Nowaczyk N and Pätzold J 2007 Dominant northern hemisphere climate control over millennial-scale glacial sea-level variability; Quat. Sci. Rev. 26 312-321.

Bardaji T, Goy J L, Zazo C, Hillaire-Marcel C, Dabrio C J, Cabero A, Ghaleb B, Silva P G and Lario J 2009 Sea level and climate changes during OIS $5 \mathrm{e}$ in the western Mediterranean; Geomorphology 104 22-37. 
Ben Baccar B 1982 Contribution à l'étude hydrogéologique de l'aquifère multi-couche de Gabès-sud; Thèse de $3^{\text {ème }}$ cycle, Université de Paris Sud, Centre d'Orsay, 116p.

Ben Ouezdou H 1983 Etudes morphologiques et stratigraphiques des formations quaternaires dans les alentours du golfe de Gabès; Thèse de doctorat, Université de Tunis, faculté des lettres et des sciences humaines, 220p.

Ben Ouezdou H 1986 Essai de corrélation des formations quaternaires continentales et marines dans les alentours du golfe de Gabès; Centre des Sciences de la Terre, Institut National de Recherche Scientifique et Technique B.P. 95, pp. 81-95.

Bouaziz S, Jedoui Y, Barrier E and Angelier J 2003 Néotectonique affectant les dépôts marins tyrrhéniens du littoral sud-est tunisien: Implications pour les variations du niveau marin; C.R. Géosci. 335 247-254.

Carter R W G 1992 Sea level changes, past, present and future; In: Applications of Quaternary research (ed.) Gray J M (Cambridge: Quaternary Research Association); Quat. Proc. 2 111-132.

Causse C, Ghaleb B, Chkir N, Zouari K, Ben Ouezdou H and Mamou A 2003 Humidity changes in southern Tunisia during the late Pleistocene inferred from U-Th dating of mollusk shells; Appl. Geochem. 18 1691-1703.

Chappell J and Shackleton N J 1986 Oxygen isotopes and sea level; Nature 324 137-140.

Dabrio C J, Zazo C, Cabero A, Goy G L, Bardaji T, Hillaire-Marcel C, Gonzalez-Delgado J A, Lario J, Silva P G, Borja F and Garcia-Blazquez A M 2011 Millennial/submillennial-scale sea-level fluctuations in western Mediterranean during the second highstand of MIS 5e; Quat. Sci. Rev. 30 335-346.

Dorale J A, Onac B P, Fornos J J, Gines J, Gines A, Tuccimei P and Peate D W 2010 Sea-level highstand 81,000 years ago in Mallorca; Science 327 860-863.

Ellouz N 1984 Etude de la subsidence de la Tunisie atlasique orientale de la mer pélagienne; $\mathrm{PhD}$ Thesis, University Paris VI, France, 122p.

Elmejdoub N and Jedoui Y 2009 Pleistocene raised marine deposits of the Cap Bon peninsula (N-E Tunisia): Records of sea-level highstands, climatic changes and coastal uplift; Geomorphology 112 179-189.

Elmejdoub N, Mauz B and Jedoui Y 2011 Sea level and climatic controls on the late Pleistocene coastal aeolianites in the Cap Bon peninsula, north-eastern Tunisia; Boreas 40 198-207.

Finkl C W 2004 Coastal classification: Systematic approches to consider in the development of a comprehensive scheme; J. Coast. Res. 20 166-213.

Gzam M, Zagrarni M F and Jedoui Y 2013 Interaction morphodynamique d'une plage sableuse dans une conjoncture d'élévation du niveau marin; exemple du littoral de Trab el Makhadha dans le golfe de Gabes-Tunisie; La Houille Blanche 3, doi: 10.1051/lhb/2013021.

Gzam M, Elmejdoub N, Boussetta S and Jedoui Y 2014 Genesis and evolution of a beach-ridge plain reflecting relative sea-level rise: A case study from trab el makhadha gulf of gabes, southeastern Tunisia; J. Sedim. Res. 84 183-191.

Goy J L and Zazo C 1989 The role of neotectonics in the morphologic distribution of the Quaternary marine and continental deposits of the Elche Basin, southeast Spain; Tectonophys. 163 219-225.

Hydrodynamica Portuguesa 1995 Extrait de l'étude générale pour la protection du littoral tunisien; 165p.

Inman D L and Nordstrom C E 1971 On the tectonic and morphologic classification of coasts; J. Geol. $\mathbf{7 9}$ $1-21$.
Jedoui Y 1979 Etude hydrologique et sédimentologique d'une lagune en domaine méditerranéen: la Bhiret el Bou Grara (Tunisie). Thèse de 3ème cycle, Univ. Bordeaux I, 190p.

Jedoui Y, Kallel N, Fontugne M, Ben Ismaïl H, M'Rabet A and Montacer M 1998 A relative sea-level stand in the middle Holocene of southeastern Tunisia; Mar. Geol. 147 123-130.

Jedoui Y 2000 Sédimentologie des dépôts littoraux quaternaires: reconstitution des variations des paléoclimats et du niveau marin dans le Sud-est tunisien. Thèse de doctorat d'état es-Sciences géologiques, Université de Tunis II, Faculté des sciences de Tunis, $330 \mathrm{p}$.

Jedoui Y, Davaud E, Ben Ismaïl H and Reyss J L 2002 Analyse sédimentologique des dépôts marins pléistocènes du Sud-Est tunisien: mise en évidence de deux périodes de haut niveau marin pendant le sous-stade isotopique marin 5e (Eémien, Tyrrhénien); Bulletin de la Société Géologique de France 173 255-264.

Jedoui Y, Reyss J L, Kallel N, Montacer M, Ben Ismail H and Davaud E 2003 U-series evidence for two high last interglacial sea levels in southeastern Tunisia; Quat. Sci. Rev. 22 343-351.

Kopp R E, Simons F J, Mitrovica J X, Maloof A C and Oppenheimer M 2009 Probabilistic assessment of sea level during the last interglacial stage; Nature 462 863-867.

Lambeck K, Esat T and Potter E K 2002 Links between climate and sea levels for the past three million years; Nature 419 199-206.

Lea D W, Martin P A, Pak D K and Spero H J 2002 Reconstructing a 350 ky history of sea level using planktonic $\mathrm{Mg} / \mathrm{Ca}$ and oxygen isotope records from a Cocos Ridge core; Quat. Sci. Rev. 21 283-293.

Mauz B, Elmejdoub N, Nathan R and Jedoui Y 2009 Last interglacial coastal environments in the MediterraneanSahara transition zone; Palaeogeogr. Palaeoclimatol. Palaeoecol. 279 137-146.

Mauz B, Fanelli F, Elmejdoub N and Barbieri R 2012 Coastal response to climate change: Mediterranean shorelines during the last interglacial (MIS 5); Quat. Sci. Rev. $5489-98$.

Mauz B, Hijma M P, Amorosi A, Porat N, Galili E and Bloemendal J 2013 Aeolian beach ridges and their significance for climate and sea level: Concept and insight from the Levant coast (East Mediterranean); Earth Sci. Rev. 121 31-54.

Mauz B, Vacchi M, Green A, Hoffmann G and Cooper A 2015 Beachrock: A tool for reconstructing relative sea level in the far-field; Mar. Geol. 362 1-16.

Morhange C and Pirazzoli P A 2005 Mid-Holocene of southern Tunisian coasts; Mar. Geol. 220 205-213.

Morzadec-Kerfourn M T 2002 L'évolution des Sebkhas du Golfe de Gabès (Tunisie), à la transition pléistocène supérieur - Holocène; Quaternaire 13 111-123.

Patriat M, Ellouz N, Dey Z, Gaulier J M and Ben Kilani H 2003 The Hammamet, Gabès and Chotts basins (Tunisia): A review of the subsidence history; Sedim. Geol. 156 241-262.

Paskoff R and Sanlaville P 1983 Les côtes de la Tunisie: variation du niveau marin depuis le Tyrrhenien (ed.) Maison de l'orient, Lyon, France, 192p.

Rohling E J, Grant K, Hemleben C H, Siddall M, Hoogakker B A A, Bolshaw M and Kucera M 2007 High rates of sealevel rise during the last interglacial period; Nature 138 42.

Roy P S P J, Cowell M A, Ferland and Thom B G 1994 Wave dominated coasts; In: Coastal evolution: Late 
quaternary shoreline morphodynamics (eds) Carter R W G and Woodroffe C D (Cambridge: Cambridge University Press), 517p.

Sammari C, Koutitonsky V G and Moussa M 2006 Sea level variability and tidal resonance in the Gulf of Gabes, Tunisia; Cont. Shelf Res. 26 338-350.

Siddall M. Chappell J and Potter E K 2006 Eustatic sea level during past interglacials; In: The Climate of Past
Interglacials (eds) Sirocko F, Claussen M, Sanchez Goñi M F and Litt T (Amsterdam: Elsevier), pp. 75-92.

Thompson W G, Curran H A, Wilson M A and White B 2011 Sea-level oscillations during the last interglacial highstand recorded by Bahamas corals; Nature Geosci. 4 684-687.

USGS Seamless Data Distribution System 2010 http://srtm. usgs.gov/data/obtainingdata.html.

MS received 2 July 2015; revised 12 September 2015; accepted 15 September 2015 